\title{
鋼製箱桁内部の環境腐食性および除湿剂による 防錆に関する研究
}

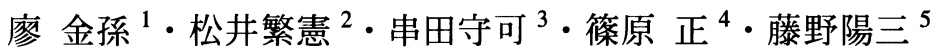 \\ ${ }^{1}$ 工博 株式会社 栗本鐵工所（广590-0977 大阪府堺市大浜 2-2） \\ 2 正会員 工修 株式会社 栗本鐵工所（干590-0977 大阪府堺市大浜 2-2） \\ 3 正会員 工博 株式会社 栗本鐵工所（广550-8580 大阪市西区北堀江 1-12-19） \\ ${ }^{4}$ 工博 独立行政法人 物質・材料研究機構（T305-0047 茨城県つくば市千現 1-2-1） \\ 5 フェロー会員 Ph. D 東京大学工学系研究科社会基盤工学専攻（T113-8656 東京都文京区本郷 7-3-1）
}

\begin{abstract}
鋼橋建設コストの低減を目的として，塗装の代わりに除湿機を箱桁内部に設置し，湿度を制御すること により, 箱桁内面の腐食を防止する工法が検討され, 実用化されている. しかし, この防食方法には電源 が必要不可欠な上, 除湿機の設置・運転費用もかかる欠点がある. これらの欠点を解決するため, 取扱い が容易で安価な除湿剂に着目し, 除湿剤による箱桁内部の湿度制御効果について検討した. 本文では, 北 海道および沖縄に架設された実橋を対象とした鋼製箱桁内部の環境腐食性の調査結果および, 腐食環境が 厳しい沖縄の実橋鋼製箱桁内部における除湿剂の湿度制御効果を解析し, 鋼板の腐食発生挙動に及ぼす不 純物付着量の影響を明らかにした上で，除湿剤を使用する鋼製箱析内部の防錆システムを提案した.
\end{abstract}

Key Words: corrosion prevention, box girder, steel bridge, ACM (ㅁtmospheric $\underline{\text { Corrosion }}$ Monitor) type corrosion sensor, humidity, desiccating agent

\section{1. はじめに}

鋼製箱桁内部の腐食は，主として現場継手ボルト連 結部, ハンドホール等の開口部からの漏水および内面 結露に起因し ${ }^{1)}$, 従来より, これを防ぐために箱析内面 に塗装を行っている. この塗装は, 通常の構造用鋼の みならず，無塗装使用を前提として開発された耐候性 鋼材に対しても施工されているのが実状である. 当然 の事ながら箱桁内面に塗装を施した場合, 初期コス卜 の他に, 定期点検, 補修塗装等のメンテナンスに関わ るコストが発生する.

塗装関係のコストを減じることによる鋼橋総コスト の低減を目的として, 近年, 箱桁内面塗装の省略が可 能となる, 箱桁内部の湿度制御による防錆技術が開発 され 2),3),4)，国内外に報告されている 5), 6),7). この防錆 技術は, 現場継手ボルト連結部, ハンドホール等の開 口部の密閉性を向上させた上で, 除湿機を使用して箱 桁内面の湿度をコントロールすることにより，箱桁内 面の腐食を抑制するものである. しかしながら，除湿
機を用いる湿度制御は, 電源が必要不可欠な上に, 設 置費用, 運転・維持管理等のランニングコスト, さら に耐久年数経過後の設備更新費用が発生する.

一方, 箱析の内部は密閉に近い構造であるため, 塩 類などの不純物の侵入がほとんどなく, 鋼材の腐食速 度は非常に小さいと考えられる. 藤野 2) は海上に架設 された鋼製箱桁内部の環境腐食性を調査し，箱桁内部 の環境が非常に緩やかであり，箱桁内部の鋼材の大気 腐食速度が約 $0.003 \sim 0.3 \mu \mathrm{m} / \mathrm{y}$ 程度であることを確認 した. 同様な調査結果は他の研究者においても得られ ている ${ }^{5), 8), 9)}$. 例えば, P.R. Vassie は水浸入がなければ 鋼製箱桁内面塗装の必要性があまりないと提言してい る $^{5 \text { ). }}$

しかし, 箱桁の密閉性を向上させることにより, 外 部からの水浸入を防止できたとしても, 相対湿度が比 較的高い地域では, 箱析内部に結露が発生し, 結露水 の生成による腐食の可能性があるため, 湿度制御が必 要であると考えられる. 結露水を防止するとの観点か ら, 本研究では, 取扱いが容易で安価な上, 半永久的 


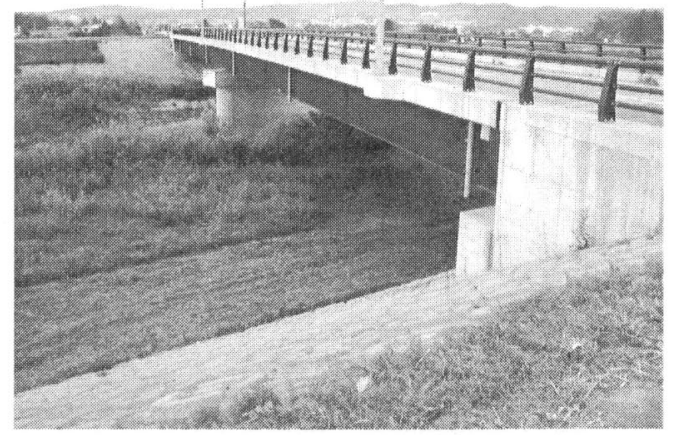

(a)外観

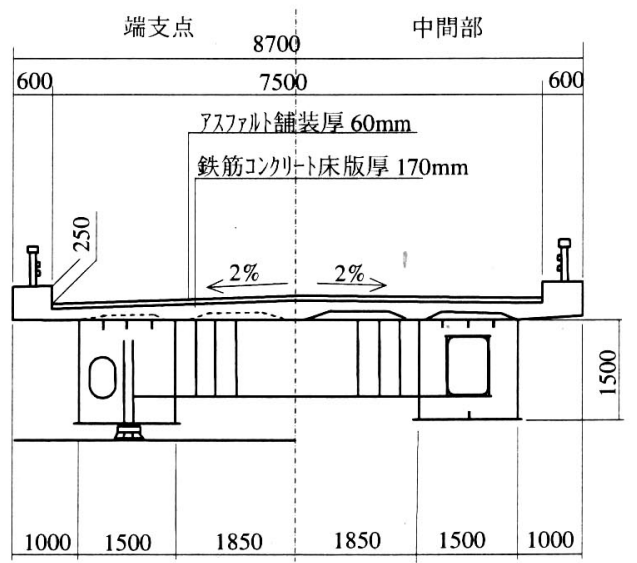

(形式 : 2 径間連続非合成箱桁, 支間割 : 2@43.9m)

(b)断面図

図-1 北海道における計測刘象の実橋（1993 年竣工）

に除湿効果を維持できる除湿剂に着目し，除湿剂によ る箱桁内部の湿度制御の効果について検討した. 本文 では，まず，北海道の田園環境および沖縄の海浜環境 に架設された実橋を対象とした鋼製箱桁内部の環境腐 食性の調査結果および，腐食環境が敩しい沖縄の実橋 鋼製箱桁内部における除湿剂の湿度制御効果を解析し, 鋼板の腐食発生挙動に及ぼす不純物付着量の影響を明 らかにした，その上で，除湿剂を使用する鋼製箱桁内 部の防錆システムを提案した.

\section{2. 箱析内部の環境腐食性}

\section{（1）環境腐食性の計測方法}

鋼製箱桁内部の環境腐食性の調査は，温度変化の激 しい北海道と海塩粒子飛来量の多い沖縄において，実

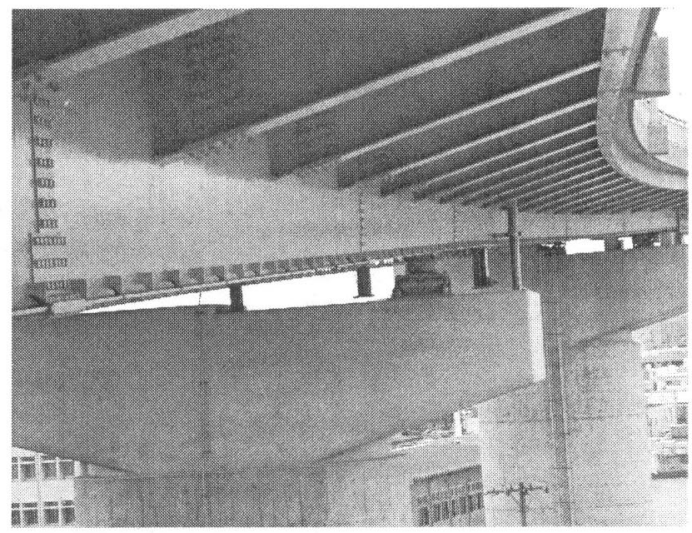

(a)外観

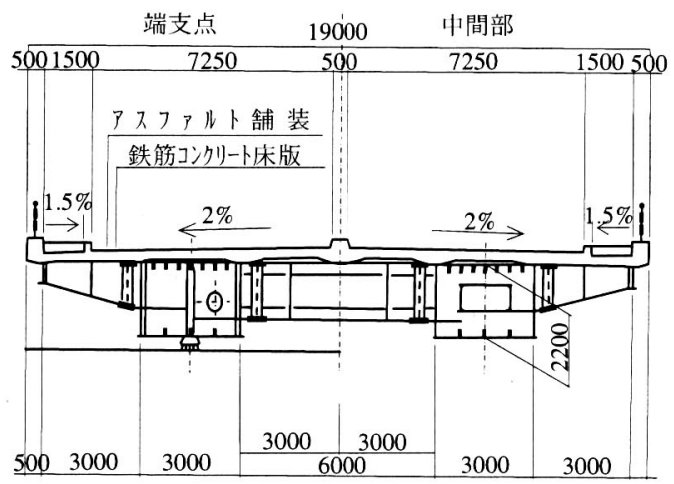

（形式：2 径間連続非合成箱桁，支間割：2@47.5m）

(b)断面図

図-2 沖縄に扮ける計測対象の実橋（1985 年竣工）

橋箱桁内部の温度, 湿度および不純物付着量を測定す ることによって行った. 測定対象の一つである北海道 の実橋は, 田園地带に架設された耐候性鋼板仕様の 2 ボックス構造で, 現場継手部にシーリング処理が施さ れ，桁内面の塗装を省略したものである（図一1）。

方, 沖縄の実橋は, 従来の普通鋼板重防食仕様の 2 ボ ックス構造で, 湾上に架設されている(図一2)。温湿 度の計測は, 温湿度センサを用いて 1 回 $/ 10$ 分の頻度 で行った，温湿度センサの設置位置は，北海道の実橋 では箱桁端部のドア開口部から約 $5 \mathrm{~m}, 65 \mathrm{~m}$ および $80 \mathrm{~m}$ の 3 箇所のウェブ部で, 沖縄の実橋では箱桁端部のド ア開口部から約 $25 \mathrm{~m}, 50 \mathrm{~m}$ および $75 \mathrm{~m}$ の 3 箇所のウェ ブ部であった。箱桁内部の温湿度の評価には， 3 䇢所 の平均値を用いた．箱桁内外部の温湿度を比較するた め, 箱桁外部の雨水が当たらないウェブの表面にも温 湿度センサを設置した。 また，鋼板表面とその近傍と 


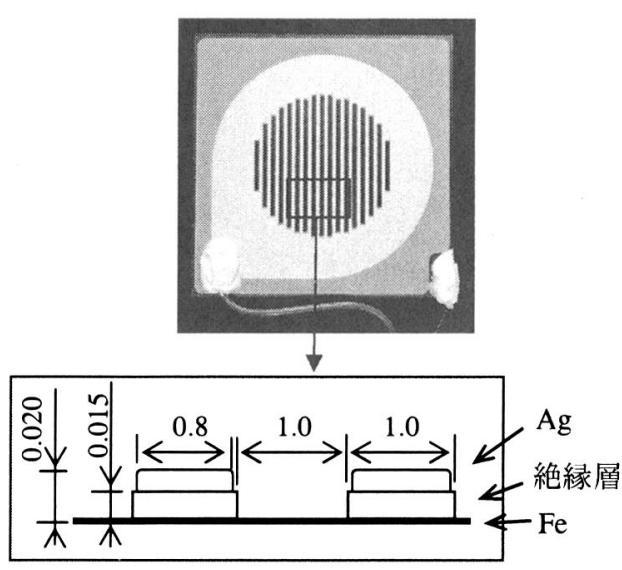

(a) ACM センサの構造（単位 : $\mathrm{mm}$ ）

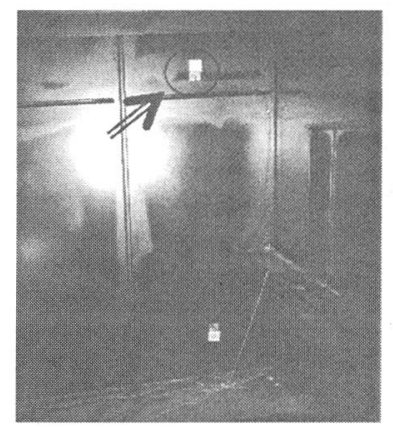

(b) ACM センサの取付け状況

図一3 ACM センサの構造及びその箱析内面における 取付状況

の温度差を把握するため, 北海道の実橋において, 箱 桁内面ウェブの鋼板表面にセンサを貼付けて，鋼板表 面温度を測定した. 不純物付着量の計測は, 塩素イオ ンおよび硫酸イオンを対象に，イオンクロマトグラフ 法で行った. 不純物の採取は, 超純水で処理した清浄 なガーゼを用いて， $0.25 \mathrm{~m}^{2}$ の面積内の不純物を拭き取 り, 拭取後のガーゼを超純水に浸漬し, 超音波洗浄に より不純物を抽出した.

また, 腐食発生挙動を明らかにするため, 沖縄の実 橋箱桁内外面ウェブ部に ACM (Atmospheric Corrosion Monitor)型腐食センサを設置し, 腐食モニタリングを行 った. 本実験で使用した ACM センサは, 図ー3に示す ように, $\mathrm{Ag}-\mathrm{Fe}$ 対 $\mathrm{ACM}$ 型腐食センサ ${ }^{10)}$ である. 同セ ンサは, 厚さ $0.8 \mathrm{~mm}$ の鉄基板の上に絶縁層を介して銀 ペーストを印刷することにより作製したもので, 結露 が発生した場合, $\mathrm{Ag}-\mathrm{Fe}$ 異種金属間に電位差が生じ, 電流が流孔る.この電流の検出により結露と腐食発生 状沇を把握することができる.

さらに, 箱桁内面の腐食速度を正確に測定するため,

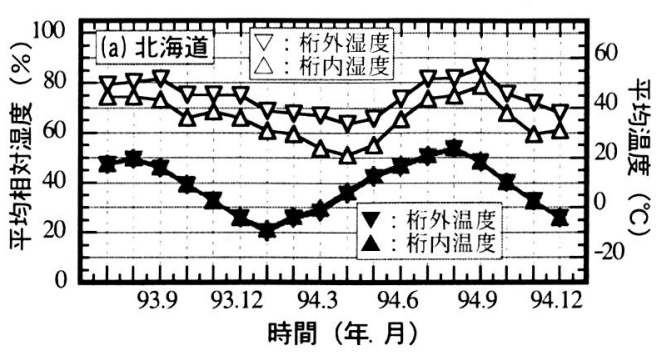

(a) 北海道

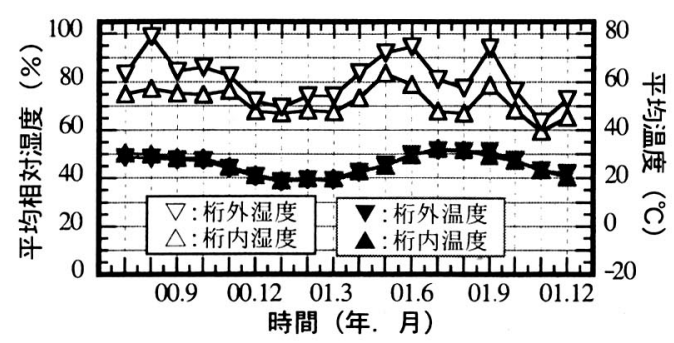

(b) 沖縄

図-4 箱桁内外の温度と湿度の月平均值

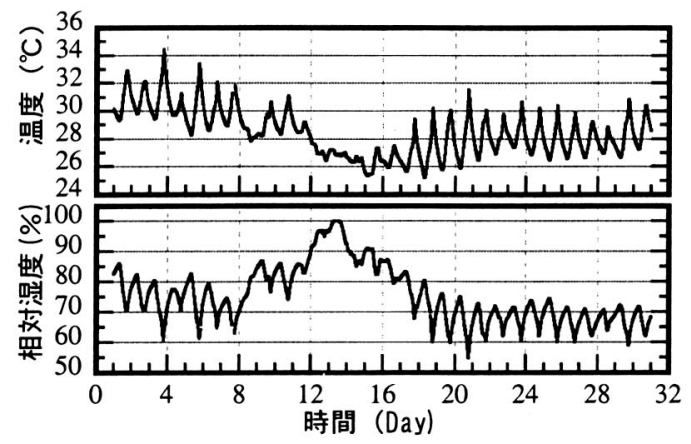

図-5 箱析内部温度と湿度の)関倸 (沖縄の自然析 内部における 2000 年 9 月の夷測值)

沖縄の実橋箱桁内面ウェブ部の水平補剛材の上（図一 3 (b) に示す上の ACM センサの取付け位置と同様な場 所）に $100 \times 60 \times 1.2(\mathrm{~mm})$ の普通炭素鋼暴露試験片を貼 付け, 暴露試験片の重量減により腐食速度を評価した.

\section{（2）箱桁内外の温湿度}

北海道および沖縄の実橋箱桁内外部の相対湿度と温 度の月平均值の経年変化を図 -4 に示す．両橋のいず れにおいても，箱析内外の相対湿度（または温度）の 月平均値の経年変化傾向がほぼ同じであることから, 箱桁内部の相対湿度および温度は，それぞれ外部の湿 度と温度に影響されていると考えられる。 また，同図 から分かるように, 温度は箱桁内外共ほぼ同じである が，相対湿度は外部より箱析内部の方が低い． 


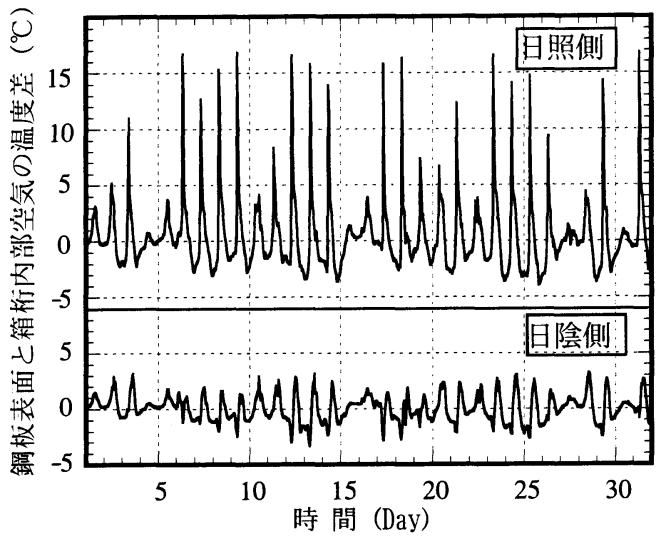

図-6 鋼板表面温度（T1）と箱桁内部気温（T2）と との温度差（T1-T2）（北海道実橋における 1994 年 5 月の実測値)

箱析内部の相対湿度は外部相対湿度以外に, 箱桁内 部の温度にも密接に関係する (図一-5). 外部大気の気 団が同一ならば，その期間では大気の絶対湿度はほと んど変化しない ${ }^{11)}$. この期間, 箱桁内部の絶対湿度も ほぼ変わらずに, 箱析内部の相対湿度は温度の日変動 に伴い変化する. すなわち, 相対湿度は, 昼間では温 度上昇に従い低くなり, 夜間では温度低下により高く なる. 雨天あるいは曼天の日（例えば, 図一 5 中の 12 〜16 日の間) では, 昼間でも温度の上昇が無く, 桁内 温度が持続的に低下し, 相対湿度は $100 \%$ になること がしばしば見受けられる。

一方, 結露と直接に関わる鋼板表面の相対湿度は, 箱桁内部空気の相対湿度のみではなく, 鋼板表面とそ の近傍の空気との温度差にも影響される. 箱桁内面ウ エブ部近傍の気温に比べ, 鋼板表面の温度は昼間では 高いが, 夜間では低くなる. このため, 夜間は結露が 発生し易い. また, 図一6 に示すように, 鋼板表面温 度とその近傍の空気との温度差は, 日照側の方が日陰 側より大きい. 北海道のような温度変化の激しい地域 では, この温度差は季節にも影響される. 温度変化が 激しい季節（例えば, 北海道では 5 月と 10 月）には, この温度差は若干大きくなる.

箱桁内外の相対湿度の年間分布を図-7 に示す. 同 図に示している沖縄の実橋箱析外部の相対湿度の実測 データでは, 相対湿度が $100 \%$ となる時間が非常に長 かった.これは, 箱桁外部に設置した温湿度センサの 周辺に飛来塩分が大量に集まり, 実際の大気中の相対 湿度が 100\%より低い時にも結露が発生し, その結果, 相対湿度が $100 \%$ と記録されたためであると考えられ る. 両橋の箱桁内外の湿度分布をみると, 北海道より 沖縄の実橋箱桁内部の相対湿度が高いことが分かる.

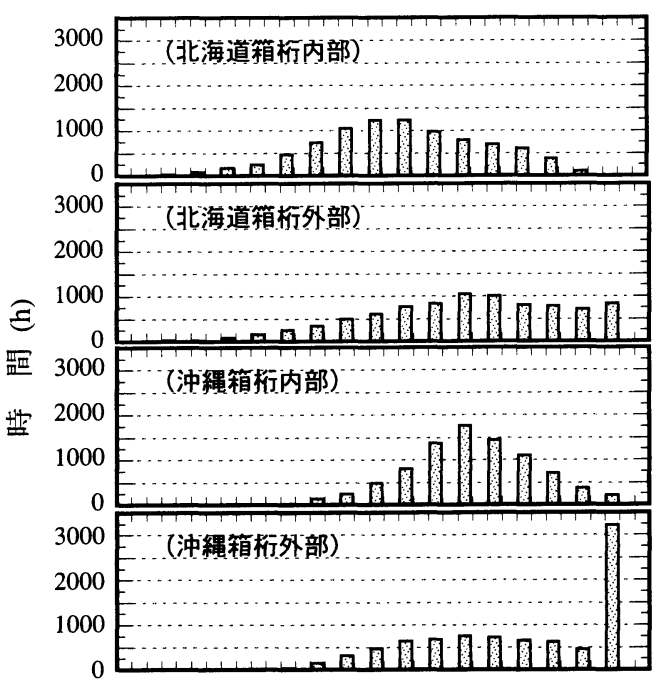

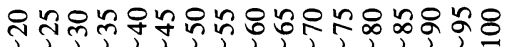

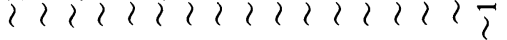
相対湿度 $(\%)$

図-7 箱析内外年間相対湿度分布（北海道実橋 : 1994 年 1 月 1994 年 12 月, 沖縄実橋 : 2000 年 8 月 ～2001 年 7 月)

表 -1 実橋箱桁内外不純物付着量（単位: $\mathrm{mg} / \mathrm{m}^{2}$ )

\begin{tabular}{|c|c|c|c|c|c|}
\hline & \multirow[t]{2}{*}{ 部 位 } & \multicolumn{2}{|c|}{$\begin{array}{l}\text { 海浜環境 (沖 } \\
\text { 縄) 通常箱析 }\end{array}$} & \multicolumn{2}{|c|}{$\begin{array}{c}\text { 田園環境(北海道) } \\
\text { 密閉処理箱桁 } \\
\end{array}$} \\
\hline & & $\mathrm{Cl}^{-}$ & $\mathrm{SO}_{4}{ }^{2-}$ & $\mathrm{Cl}^{-}$ & $\mathrm{SO}_{4}{ }^{2-}$ \\
\hline \multirow{4}{*}{$\begin{array}{l}\text { 析 } \\
\text { 内 }\end{array}$} & ウェブ 部 & 0.5 & 8.2 & 0.11 & 0.35 \\
\hline & 床部 & 140 & 110 & 0.14 & 2.1 \\
\hline & 林ラップ 部 & 29 & 180 & - & - \\
\hline & ドア部 & 7.8 & 51 & 0.04 & 0.62 \\
\hline \multirow{2}{*}{\begin{tabular}{|l|} 
标 \\
外
\end{tabular}} & ウエブ 部 & 3.4 & 8.7 & - & - \\
\hline & ドア部 & 55 & 500 & 0.24 & 5.1 \\
\hline
\end{tabular}

特に, 沖縄の実橋箱析内部では, 相対湿度 95〜100\% の時間が年間約 220 時間と非常に長く, 箱桁内部に結 露水が生じる可能性が高い.

\section{（3）箱析内外の不純物付着量}

北海道および沖縄における実橋の箱桁内外の塩素入 オン $\left(\mathrm{Cl}^{-}\right)$および硫酸イオン $\left(\mathrm{SO}_{4}{ }^{2-}\right)$ の付着量の測定結 果を表-1 に示す. 沖縄の海浜環境にある実橋に比べ て, 北海道の田園環境にある実橋では, 箱桁内部の不 純物付着量が極めて少ない. 北海道の実橋箱桁内部で は, 塩素イオン濃度が約 $0.1 \sim 0.2 \mathrm{mg} / \mathrm{m}^{2}$ で, 硫酸イオ ン濃度が $2.1 \mathrm{mg} / \mathrm{m}^{2}$ 以下であった.

一方, 沖縄の実橋では, 箱桁内部の不純物付着量は 


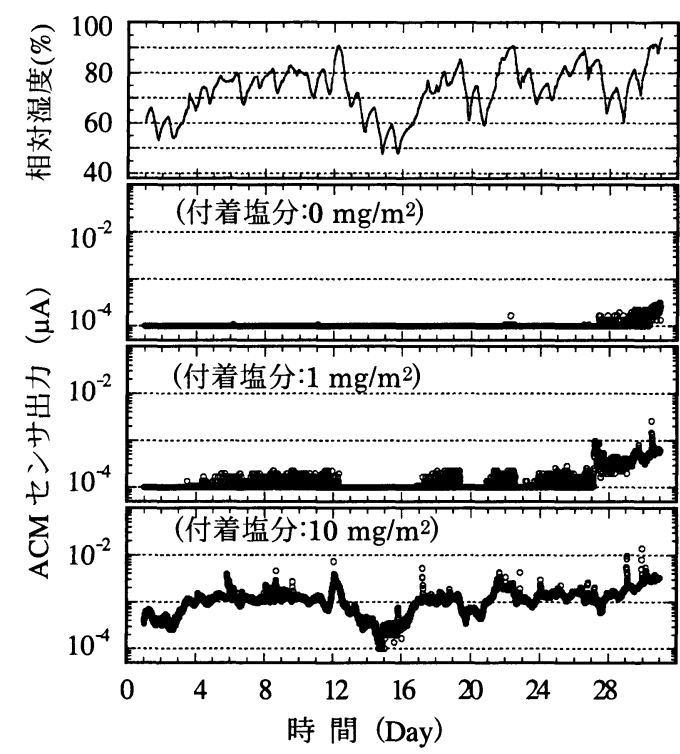

図-8 ACM センサ出力に及ぼす塩分と湿度の影響（沖縄 実橋の自然桁内における 2001 年 4 月の実測值)

部位によってかなり異なる. 人の出入りの影響を受け た床部および箱桁内部と外部の空気交換の経由部位で あるスカラップ部では不純物付着量が非常に多いが, ドア部, 特に一般ウェブ部では不純物付着量が少なく, 塩素イオン濃度が $0.5 \mathrm{mg} / \mathrm{m}^{2}$ で, 硫酸イオン濃度が 10 $\mathrm{mg} / \mathrm{m}^{2}$ 以下であった.
箱析外部については，従来報告されているとおり， 雨水の洗浄作用を受けるウェブ部に比べて, 雨水の当 たらないドア部の不純物付着量が多かった.

\section{（4）箱析内部の腐食発生挙動}

実橋箱桁内面の腐食発生挙動に及ぼす不純物付着量 の影響を検討するため，沖縄の実橋箱桁内面ウェブ部 に, 表面に塩分を付着させた ACM センサを貼付け (図 -3 参照), ACM センサ出力を計測した. ACM センサ 表面に付着させた塩分 $(\mathrm{NaCl})$ 量は，0，0.1，1 および 10 $\mathrm{mg} / \mathrm{m}^{2}$ の 4 条件であった.

表面塩分付着量がそれぞれ 0,1 および $10 \mathrm{mg} / \mathrm{m}^{2}$ の $\mathrm{ACM}$ センサ出力の経時変化を図ー8 に示す. 塩分付着 量が $0.1 \mathrm{mg} / \mathrm{m}^{2}$ の ACM センサ出力の挙動は塩分付着量 が $0 \mathrm{mg} / \mathrm{m}^{2}$ の場合とほぼ同様であった.

図-8 から明らかなように, ACM センサの出力は, 箱桁内部の湿度および ACM センサ表面塩分付着量に 影響される. 表面塩分付着量が $0,0.1 \mathrm{mg} / \mathrm{m}^{2}$ では, 相 対湿度に関わらず, $5 \times 10^{-4} \mu \mathrm{A}$ 以上 ${ }^{10)}$ の有意な $\mathrm{ACM} セ$ ンサ出力は見られなかった. 表面塩分付着量が $1 \mathrm{mg} / \mathrm{m}^{2}$ では, 相対湿度が $85 \%$ 以上の場合, 有意な ACM セン サの出力が度々認められたが, 相対湿度が $85 \%$ 以下の 場合, 有意な出力は無かった. また, 塩分付着量が 10 $\mathrm{mg} / \mathrm{m}^{2}$ の場合, 有意な $\mathrm{ACM}$ センサ出力が観察された最 低湿度は約 55\%であった．相対湿度が同じ場合，塩分 付着量が多いほど, ACM センサの出力は大きくなる.

表－2 IS09223 に基づく箱析内部環境腐食性評価

\begin{tabular}{|c|c|c|c|c|c|c|c|c|c|}
\hline \multicolumn{3}{|c|}{ 結露の影響 } & & \multicolumn{6}{|c|}{ 污染物質の影響 } \\
\hline \multicolumn{2}{|c|}{$\begin{array}{l}\text { 結露時間 } \\
\text { hour/year }\end{array}$} & 分類 & \multicolumn{2}{|c|}{$\begin{array}{c}\mathrm{SO}_{2} \text { 付着速度 } \\
\mathrm{mg} /\left(\mathrm{m}^{2} \cdot \mathrm{d}\right)\end{array}$} & \multicolumn{2}{|c|}{ 分類 } & \multicolumn{2}{|c|}{$\begin{array}{c}\text { 塩分付着速度 } \\
\mathrm{mg} /\left(\mathrm{m}^{2} \cdot \mathrm{d}\right)\end{array}$} & 分類 \\
\hline \multicolumn{2}{|c|}{$\tau \leqq 10$} & $\tau_{1}$ & \multicolumn{2}{|r|}{$P_{d} \leqq 10$} & \multicolumn{2}{|c|}{$\mathbf{P}_{0}$} & \multicolumn{2}{|l|}{$\mathrm{S} \leqq 3$} & $S_{0}$ \\
\hline \multicolumn{2}{|c|}{$10<\tau \leqq 250$} & $\overline{\tau_{2}}$ & \multicolumn{2}{|r|}{$10<P_{d} \leqq 35$} & \multicolumn{2}{|c|}{$\mathrm{P}_{1}$} & \multicolumn{2}{|c|}{$3<S \leqq 60$} & $S_{1}$ \\
\hline \multicolumn{2}{|c|}{$250<\tau \leqq 2500$} & $\tau_{3}$ & \multicolumn{2}{|r|}{$35<P_{d} \leqq 80$} & \multicolumn{2}{|c|}{$\mathrm{P}_{2}$} & \multicolumn{2}{|c|}{$60<S \leqq 300$} & $S_{2}$ \\
\hline \multicolumn{2}{|c|}{$2500<\tau \leqq 5500$} & $\tau_{4}$ & & $30<P_{d} \leqq 200$ & $\mathrm{P}_{3}$ & & $300<S \leqq 15$ & & $S_{3}$ \\
\hline \multicolumn{10}{|c|}{ 鉄鋼材料に対する大気環境腐食性評価 } \\
\hline & \multicolumn{3}{|c|}{$\overline{\tau_{1}}$} & \multicolumn{3}{|c|}{$\tau_{2}$} & \multicolumn{3}{|c|}{$\tau_{3}$} \\
\hline & $S_{0}-S_{1}$ & $\mathrm{~S}_{2}$ & $S_{3}$ & $S_{0}-S_{1}$ & $S_{2}$ & $S_{3}$ & $S_{0}-S_{1}$ & $S_{2}$ & $\mathrm{~S}_{3}$ \\
\hline$\overline{P_{0}-P_{1}}$ & $\overline{C_{1}}$ & $\mathrm{C}_{1}$ & $\mathrm{C}_{1}$ or $\mathrm{C}_{2}$ & $\mathrm{C}_{1}$ & $\mathrm{C}_{2}$ & $\mathrm{C}_{3}$ or $\mathrm{C}_{4}$ & $\mathrm{C}_{2}$ or $\mathrm{C}_{3}$ & $\mathrm{C}_{3}$ or $\mathrm{C}_{4}$ & $\mathrm{C}_{4}$ \\
\hline$P_{2}$ & $\mathrm{C}_{1}$ & $\mathrm{C}_{1}$ & $\mathrm{C}_{1}$ or $\mathrm{C}_{2}$ & \begin{tabular}{l|l|}
2 & $C_{1}$ or $C_{2}$ \\
\end{tabular} & $\mathrm{C}_{2}$ or $\mathrm{C}_{3}$ & $\mathrm{C}_{3}$ or $\mathrm{C}_{4}$ & \begin{tabular}{l|l}
-4 & $C_{3}$ or $C_{4}$ \\
\end{tabular} & $\mathrm{C}_{3}$ or $\mathrm{C}_{4}$ & $\mathrm{C}_{4}$ or $\mathrm{C}_{5}$ \\
\hline $\mathrm{P}_{3}$ & $\mathrm{C}_{1}$ or $\mathrm{C}_{2}$ & $\mathrm{C}_{1}$ or $\mathrm{C}_{2}$ & $\mathrm{C}_{2}$ & $\mathrm{C}_{2}$ & $\mathrm{C}_{3}$ & $\mathrm{C}_{4}$ & $\mathrm{C}_{4}$ & $\mathrm{C}_{4}$ or $\mathrm{C}_{5}$ & $\mathrm{C}_{5}$ \\
\hline & & & & 鉄鋼材料の & 腐食速度 & & & & \\
\hline & 分类 & & & & & 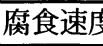 & 度 $(\mu \mathrm{m} / \mathrm{y})$ & & \\
\hline & $\mathrm{C}_{1}$ & & & & & $r_{\text {corr }} \cong$ & $\leqq 1.3$ & & \\
\hline & $\mathrm{C}_{2}$ & & & & & $1.3<r_{c}$ & $\operatorname{com} \leqq 25$ & & \\
\hline & $\mathrm{C}_{3}$ & & & & & $25<r_{c c}$ & $\mathrm{corr} \leqq 50$ & & \\
\hline & $\mathrm{C}_{4}$ & & & & & $50<r_{c c}$ & corr $\leqq 80$ & & \\
\hline & $\mathrm{C}_{5}$ & & & & & $80<r_{\text {col }}$ & orr $\leqq 200$ & & \\
\hline
\end{tabular}




\section{（5）箱桁内部環境腐食性の評価}

大気環境の腐食性は, 国際規格 ISO9223 (Corrosion of metals and alloys - Corrosivity of atmospheres Classification)に基づき, 結露時間および污染物質の量 で評価できる. 同規格においては, 結露時間は $0^{\circ} \mathrm{C}$ 以 上で相対湿度が $80 \%$ 以上の時間を指し, 污染物質の量 は, 大気中の $\mathrm{SO}_{2}$ と海塩粒子量（一般に, 塩素イオン $\mathrm{Cl}^{-}$濃度) である.

ISO9223 に基づく大気噮境腐食性の評価方法を表一 2 に示す．北海道の実橋箱桁内部では，相対湿度 $80 \%$ 以上の時間は年間 1085 時間であり， $\tau_{3}$ 範囲内 $(250$ 〜 2500 時間)にある. 污染物質 $\mathrm{SO}_{2}$ の量は測定されていな いが, $\mathrm{SO}_{4}{ }^{2-}$ の付着量 $\left(0.35 \sim 2.1 \mathrm{mg} / \mathrm{m}^{2}\right)$ から判断すれ ば, $\mathrm{P}_{0}$ （付着速度 $\leqq 10 \mathrm{mg} /\left(\mathrm{m}^{2} \cdot\right.$ day $)$ ）の範囲内にあると 考えられる. また, 飛来塩分量は $0.04 \sim 0.14 \mathrm{mg} / \mathrm{m}^{2}$ で, $\mathrm{S}_{0}$ （付着速度 $\leqq 3 \mathrm{mg} /\left(\mathrm{m}^{2} \cdot\right.$ day)）の範囲内にある. した がって, 鋼板の腐食速度は $\mathrm{C} 2 \sim \mathrm{C} 3$, すなわち $1.3 \sim 50$ $\mu \mathrm{m} / \mathrm{y}$ となる. これに対して, 沖縄の実橋箱桁内部で は, 相対湿度 $80 \%$ 以上の時間は年間約 2401 時間であ るが, 北海道の実橋箱桁内部之同様に, $\tau_{3}$ 範囲内にあ る. また, $\mathrm{SO}_{4}{ }^{2-}$ の付着量は $8.2 \sim 180 \mathrm{mg} / \mathrm{m}^{2}$ であり, こ の付着量から判断すれば, 沖縄の実橋箱桁内部におい ても, 污染物質 $\mathrm{SO}_{2}$ の量は $\mathrm{P}_{0}$ の範囲内にあると考えら れる. 飛来塩分量 $\left(0.5 \sim 140 \mathrm{mg} / \mathrm{m}^{2}\right)$ も, 北海道の実橋 箱析内部之同様に, $\mathrm{S}_{0}$ の範囲内にあると考えられる. すなわち, 北海道に比べて, 沖縄の実橋箱桁内部にお ける相対湿度 $80 \%$ 以上の時間および污染物質量は多い が, ISO9223 に基づいて評価すれば, 箱桁内部の環境 腐食性は同程度（1.3〜 50 $\mu \mathrm{m} / \mathrm{y} ）$ となる.

上述のように, ISO9223 規格に基づく大気環境腐食 性の評価では, 腐食速度の範囲は概ね把握できるが, 具体的な腐食速度は分からない. 箱析内部の大気腐食 性をより詳細に把握するため, ここでは, 沖縄実橋箱 桁内部の現地試験で得られた $\mathrm{ACM}$ センサ出力 $\times$ 時間 （すなわち, 電気量) の総和と不純物付着量との関係 (図ー9) および, 実験室での試験結果 ${ }^{10)}$ から得られた 電気量と鋼材腐食速度の関係（図一10）を用いて, 箱 桁内部の各部位での鋼材腐食速度を求めることにした.

図ー9 と図ー10を用いて推算した両橋の箱析内面の 各部位の腐食速度を表-3に示す. 図ー9 に示す不純物 付着量と電気量との関係は沖縄の実橋箱桁内部の実測 結果であるため, 北海道の実橋の箱桁内部の腐食性評 価に使用される場合, 得られた鋼材の腐食速度が実際 の状況よりやや大きくなる可能性がある. また, 沖縄 の実橋箱桁内面の床およびスカラップ部位については, 不純物付着量が非常に多く, 図ー9 の範囲を超えてい

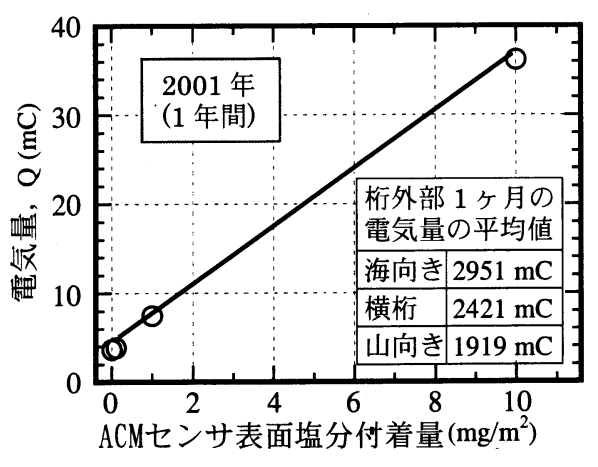

図-9 電気量に及ぼす不純物付着量の影響

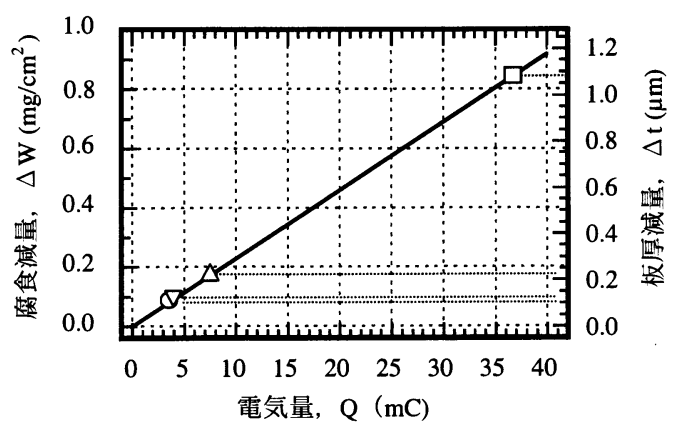

図-10 ACM センサ出力（電気量）と腐食速度の関係 ${ }^{10}$ 及びそれによる沖縄箱析内部の腐食速度の推測 (塩分付着量 : $\bigcirc 0 \mathrm{mg} / \mathrm{m}^{2}, \nabla 0.1 \mathrm{mg} / \mathrm{m}^{2}, \triangle 1.0 \mathrm{mg} / \mathrm{m}^{2}$, $\left.\square 10 \mathrm{mg} / \mathrm{m}^{2}\right)$

表 -3 実橋箱桁内外の各部位の腐食速度（単位: $\mu \mathrm{m} / \mathrm{y} ）$

\begin{tabular}{|c|c|c|c|}
\hline \multicolumn{2}{|r|}{ 部 位 } & $\begin{array}{l}\text { 海浜環境（沖 } \\
\text { 縄）通常箱桁 }\end{array}$ & $\begin{array}{l}\text { 田園環境(北海道) } \\
\text { 密閉処理箱桁 }\end{array}$ \\
\hline \multirow{4}{*}{$\begin{array}{l}\text { 桁 } \\
\text { 内 }\end{array}$} & ウエブ 部 & 0.20 & 0.13 \\
\hline & 床部 & - & 0.15 \\
\hline & 扐ラップ 部 & - & - \\
\hline & ドア部 & 1.40 & 0.10 \\
\hline \multirow{2}{*}{$\begin{array}{l}\text { 栴 } \\
\text { 外 }\end{array}$} & ウエブ 部 & 0.68 & - \\
\hline & ドア部 & - & 0.18 \\
\hline
\end{tabular}

るため, 正確な腐食速度は算定できなかった. なお, 不純物から電気量を推算する時に, 箱析内面に付着し た污染物質 $\mathrm{SO}_{2}$ の影響を無視し, 付着塩分量の影響の みを考慮した. 表一3 から分かるように, 北海道の実 橋箱桁内面の腐食速度が極めて小さく, 沖縄の実橋箱 桁内面においても, ドア部, 特に一般ウェブ部の腐食 速度が $1 \mu \mathrm{m} / \mathrm{y}$ 以下で非常に小さい. 
上述の計算結果の妥当性は沖縄の実橋箱桁内部にお ける暴露試験により確認されている. 塩分付着量が 0 , $1.0,10 \mathrm{mg} / \mathrm{m}^{2}$ の場合, 暴露試験片鋼材の腐食速度がそ れぞれ $0.38,0.55,1.65 \mu \mathrm{m} / \mathrm{y}$ であり, 計算結果とほぼ 同程度である。

実橋箱析内部の大気腐食性に関する測定結果から分 かるように, 田園環境に架設される実橋の箱桁内面で は不純物付着量が極めて少ない．沖縄の実橋のように 海浜環境に架設された箱桁内面においても, 設計段階 における密閉性の向上, 架設時における箱析内面への 不純物付着の防止対策, 架設後における人の出入りの 制限，あるいは，点検時の土足での出入りに対する措 置を講じれば，不純物付着量は一般ウェブ部のような 低レベルに抑えることが可能である. 不純物付着量が 少ない場合, 外部からの水浸入および結露水の生成が 無ければ, 鋼板腐食速度は極めて小さい. したがって, 箱桁内面を無塗装にする場合，まず，構造の密閉性を 向上させることにより, 飛来塩分の侵入と漏水を防止 することが必要であり，さらに，箱桁内部の湿度を制 御することにより結露水の生成を防ぐことが重要であ る. 以下では, 除湿剂による湿度制御効果, とりわけ 結露水生成（すなわち, 箱桁内部空気の相対湿度が $100 \%$ に到達すること）の防止の可能性について検討す る.

\section{3. 除湿剂による湿度制御}

\section{（1）除湿剤の特性および設置方法}

沖縄の実橋において, 一方の箱析内部に除湿剤を設 置し，他方の箱桁は自然状態にすることで，除湿剤に よる箱桁内面の湿度制御と結露水生成の防止効果を検 証した. 以下では, 除湿剤を設置した箱析を除湿析と, 自然状態にある箱桁は自然桁と略記する. 除湿桁に設 置した除湿剂は，日本工業規格 JIS Z 0701 に定めてい る B 型のシリカゲル乾燥剤で，粒子状の多孔質のケイ 酸 $\left(\mathrm{SiO}_{2}\right)$ のゲルであった. この乾燥剤 (B 型) と従 来一般に使用されている乾燥剤 (A 型) との違いは, A 型のシリカゲルは表面積が大きく, 細孔容積が小さ いことに対して, B 型のシリカゲルは表面積が小さく, 細孔容積が大きいことにある. A 型のシリカゲルは, 化学的な表面吸着が主要な吸湿方式で, 低湿度での吸 湿率が大きい。一方, B 型のシリカゲルは, 物理的な 毛細管凝縮が主要な吸湿方式で, 低湿度での吸湿率が 小さいが，高湿度での吸湿率は非常に大きい. また, $\mathrm{A}$ 型のシリカゲルは化学的吸着方式であるため, 一定

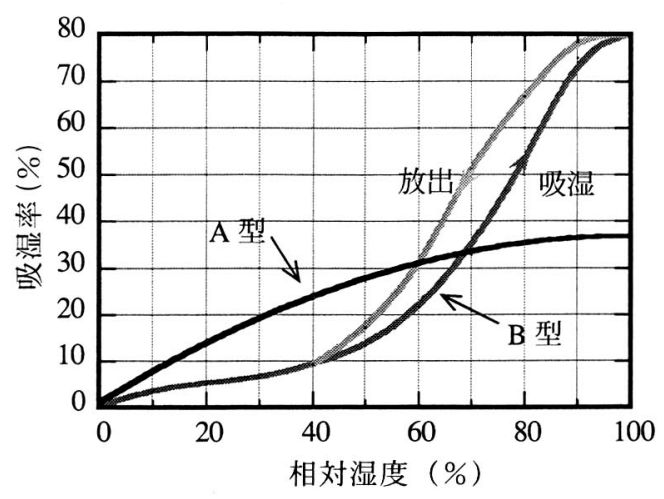

（a）除湿剂の吸湿特性

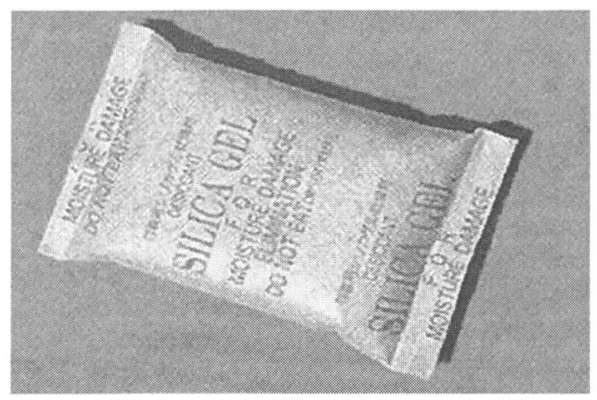

(b) 除湿剂の包装状況

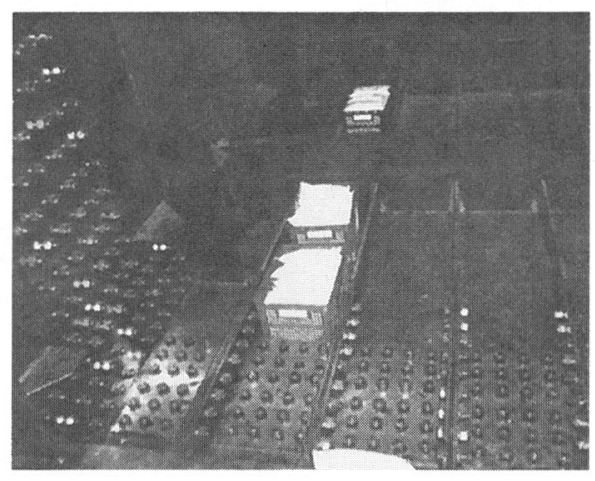

(c) 除湿剂の設置状況

図-11 除湿剂の吸湿特性と設置状況

量の水分を吸着すると除湿能力を失い, シリカゲルの 再利用に約 $120^{\circ} \mathrm{C}$ での加熱処理が必要である.これに 対して， B 型のシリカゲルは物理的な吸着方式である ため, 常温でも周囲の湿度が低い時に, 自動的に吸着 水分を放出する.すなわち，本研究に使用した除湿剤 （B 型シリカゲル）は，周囲湿度が高い時に吸湿し， 周囲湿度が低い時に水分を放出する特性を持ち，シリ カゲルの毛細管構造が破壊されていない限り，半永久 的に吸湿効果が期待できるものである. A , B 型のシリ 
カゲルの吸湿特性を図ー11 (a) に示す. 図中の吸湿率は 次式によるものである.

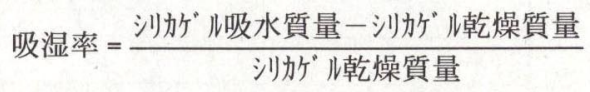

$$
\begin{aligned}
& \times 100 \%
\end{aligned}
$$

除湿析内部に設置した除湿剤の量(W)は，日本工業規 格JS Z 0301 ${ }^{12)}$ に準拠して, 次式により算出した.

$$
\mathrm{W}=\mathrm{V} \cdot \mathrm{H} /\left[(\mathrm{C} 2-\mathrm{C} 1) \times 10^{-2}\right]
$$

式(2)において, Vは箱桁内部空間容積 $\left(\mathrm{m}^{3}\right)$ で, Hは気 象デー夕に基づく鋼橋所在地の大気中の絶対湿度の年 平均值 $\left(\mathrm{g} / \mathrm{m}^{3}\right)$ である. また, $\mathrm{C} 1$ は鋼橋所在地の大気相 対湿度の年平均值における除湿剤の吸湿と放出過程の 吸湿率の平均值（\%）で, $\mathrm{C} 2$ は箱桁内部の許容される 最高相対湿度における除湿剤の吸湿過程の吸湿率（\%) である. 箱桁内部の許容される最高相対湿度は, 結露水 の発生を抑えることができる最高湿度であり,鋼板表面 と箱桁内部空気との温度差および箱析内面の不純物付 着量に依存するが, ここでは, 沖縄の温度変化および箱 桁内面の不純物付着量を考慮して, 85\%とした. 実際, 沖縄実橋の除湿析に250kgのB型のシリカゲルを設置し た.

除湿析内部における除湿剤の配置には, 除湿剂の吸湿 効率と配置作業の便利性の両方を考慮することが必要 である. 除湿剤の吸湿能力を高めるためには, 除湿剤を 箱桁内部に均一に分散させることが最も望ましいが, 除 湿剤自体を箱桁内部にばらまくことが出来ないので, 水 蒸気透過率が良いポリエステル不織布の袋に包装され た状態（図ー11 (b)）で設置することが現実的である. 本実験では, 除湿剂を除湿析の現場継手ボルト連結部お よび析の両端部に配置し, 配置数量は, 桁両端部を除い て均等にした. 桁両端部では, 桁外部からの湿気が侵入 し易いため, 除湿剂の配置数量を現場継手ボルト連結部 近傍の2倍にした. 現場継手ボルト連結部における除湿 剤の設置状況を図-11 (c)に示す. なお，本実験では， 除湿剂の購入, 現地への輸送および設置等の諸費用は合 計45万円程度であった.

\section{(2) 除湿剤による湿度制御効果}

除湿剤設置直後および一年間経過後の箱桁内部相対 湿度の経時変化を図ー12 に示す. 同図(a)に示されてい るように, 除湿剤無しの自然桁に比べて, 除湿桁内部 の相対湿度は, 除湿剤設置直後 (6 月中旬) に急激に 低下し, その後, 徐々に上昇する. 約 2 ケ月後に, 自 然析の相対湿度に接近するが，ほぼ $85 \%$ 以下に制御さ れている. また, 同図(b)から明らかなように，一年間 経過後も, 自然桁内部では相対湿度が度々 $100 \%$ に達し たが, 除湿桁内部では相対湿度がほぼ $85 \%$ 以下であっ

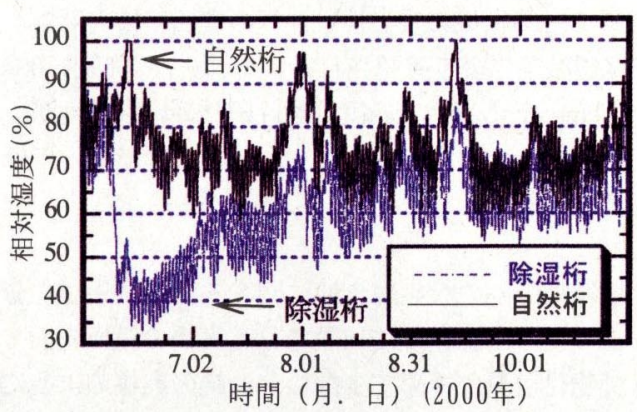

(a)設置直後

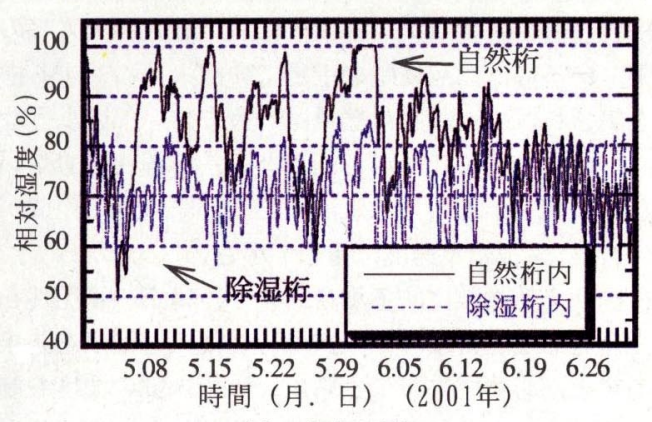

(b) 一年経過後

図-12 除湿剂による除湿勃果

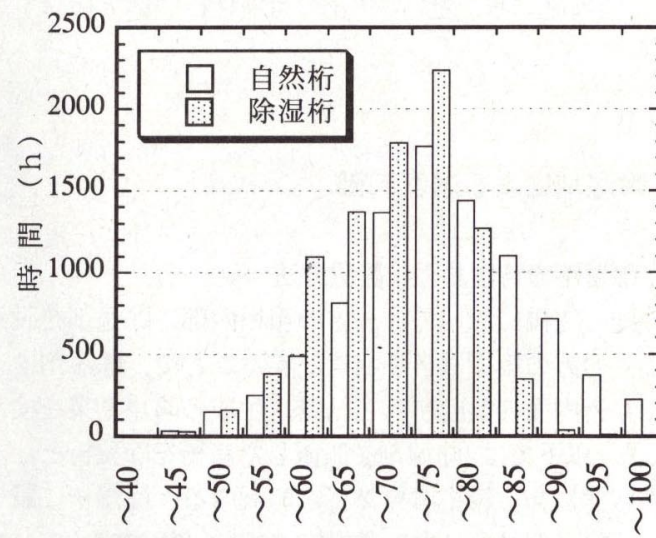

相対湿度 $(\%)$

図-13 自然析と除湿析内部の年間相対湿度分布の比較 （2000年 8 月～ 2001 年 7 月）

た. すなわち, 除湿剤の湿度制御効果は長期間維持さ れている.

除湿析内部の相対湿度の年間分布を図ー13 に示す. 相対湿度 $85 \%$ 以上の時間は自然桁内部では年間 1303 時間であるが，除湿桁内部では 36.8 時間であった. ま

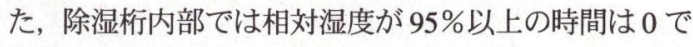
あった.

上述のように，除湿剤を設置した除湿桁では，相対 
湿度がほぼ $85 \%$ 以下に制御されている.このような相 対湿度レベルでは, 不純物付着量が比較的少ない箱桁 内部において, 箱桁内部気温より鋼板表面温度が 2 $3^{\circ} \mathrm{C}$ 程度低くなっても, 結露水が発生しにくいと考えら れる。

\section{4. 除湿剂使用の箱桁内面の鋼材腐食に及ぼす不 純物付着量の影響}

上述のように，除湿剤を箱桁内部に設置することに より, 箱桁内部の相対湿度を長期間 $85 \%$ 以下にコント ロールすることは可能であり, 結露水の発生を防止で きる. しかし, 結露水が発生しなくても, 不純物付着 量が多ければ，相対湿度を $85 \%$ 以下に抑えても腐食が 発生する可能性がある. したがって, 除湿剤を設置す る場合の鋼板腐食速度に及ぼす不純物付着量の影響, とりわけ鋼板の発錆を防止するための許容最大不純物 付着量を明確にすることが必要である. このため, 自 然桁と除湿桁共に, 桁内部にACMセンサおよび暴露試 験片を設置し，腐食発生のモニタリングおよび鋼板腐 食速度の計測を行った. なお，ACMセンサ表面には， $0,0.1 ， 1$ および $10 \mathrm{mg} / \mathrm{m}^{2}$ の塩分 $(\mathrm{NaCl})$ を付着し, 暴露

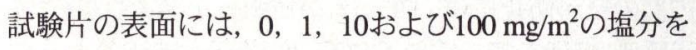
付着した.
箱析内部で一年間暴露した試験片の腐食減量を図ー 14, 試験片の表面状況を図ー15に示す. 塩分付着量が 0.1 および $1 \mathrm{mg} / \mathrm{m}^{2}$ の場合では, 自然桁と除湿桁とも腐食が ほとんど発生せず, 腐食速度は非常に小さかった（図一 14).ただし，暴露試験片の表面状況を詳細に観察すれ ば, 極僅かであるが, 自然析内部に暴露した試験片表面 に赤錆が観察された.これに対して, 除湿桁内部の試験 片には発錆が認められなかった（図ー15）.

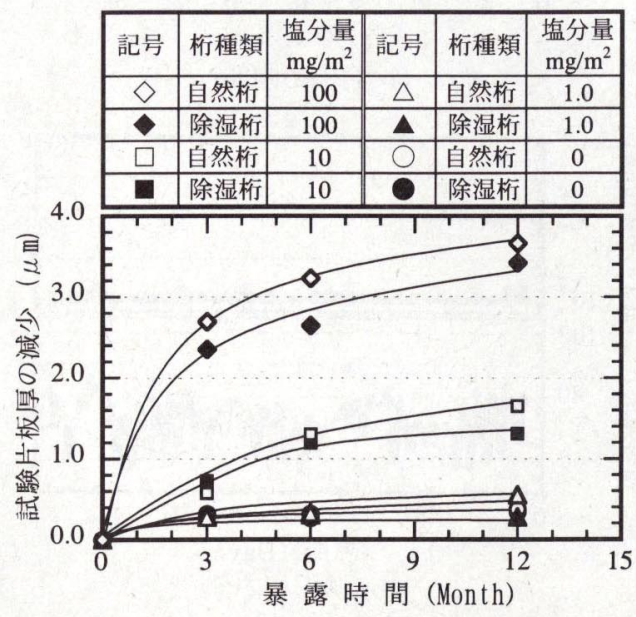

図-14 暴露試験片腐食減量

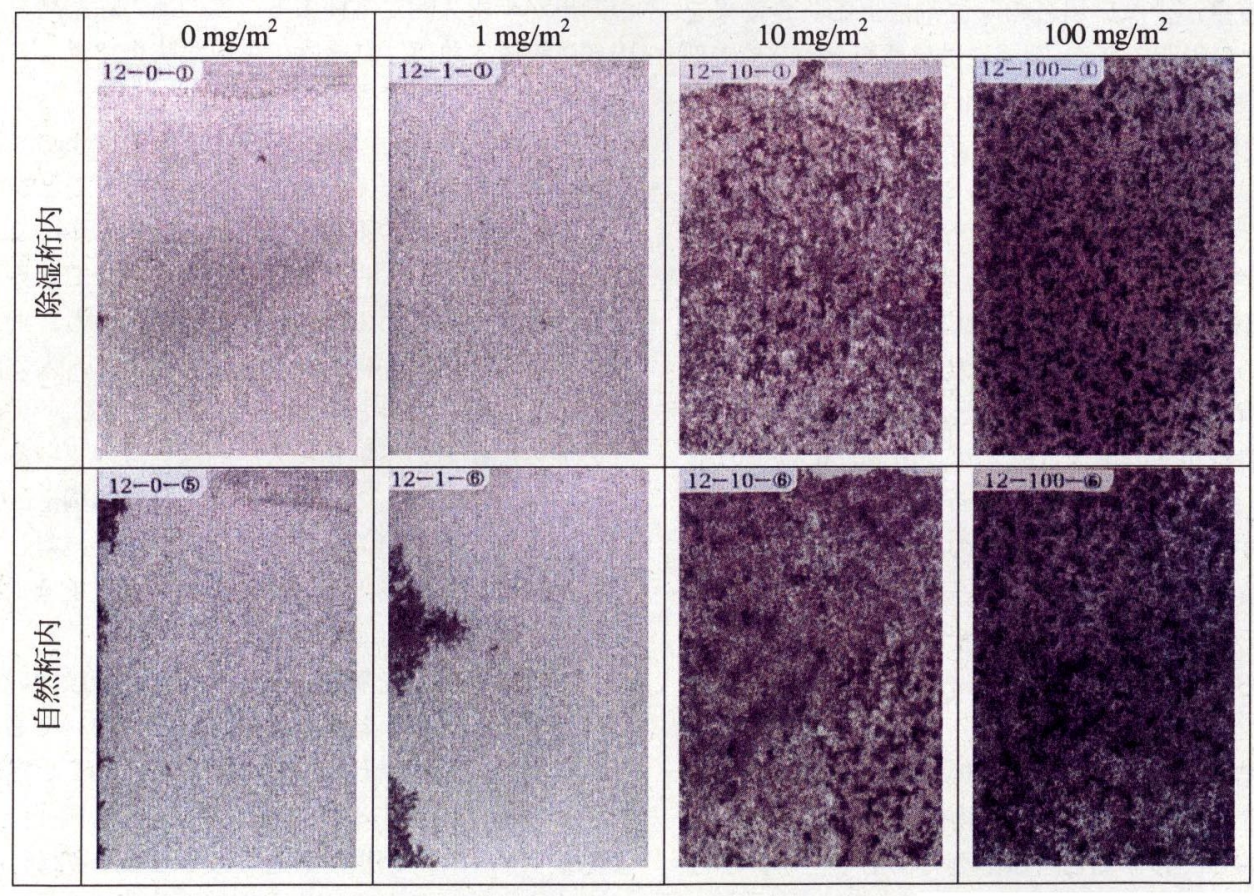

図-15 一年間暴露した試験片の表面状況 


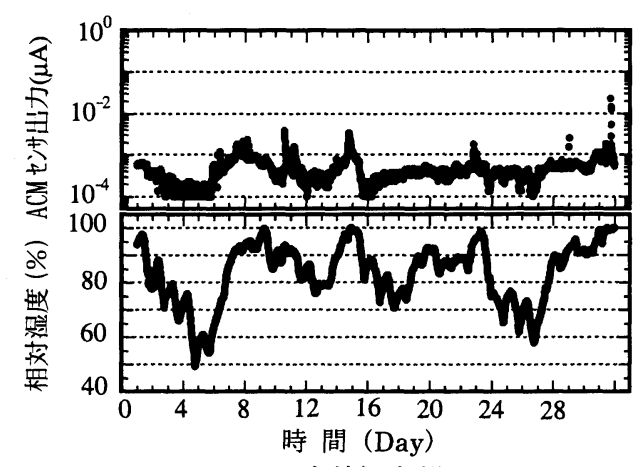

(a) 自然桁内部

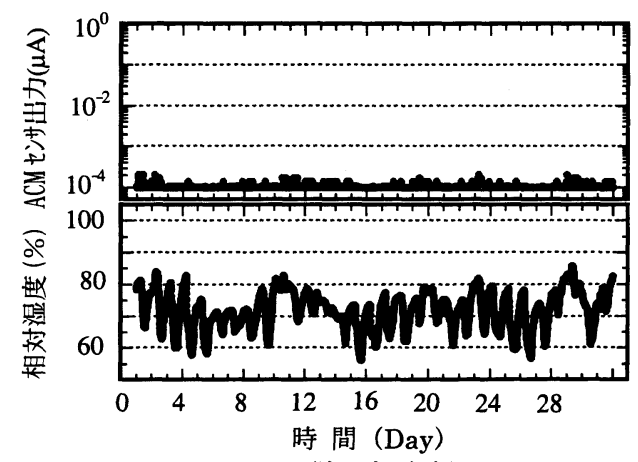

(b) 除湿析内部

図-16 除湿剂による湿度制御と腐食抑制（ACM セ ンサ表面に $1 \mathrm{mg} / \mathrm{m}^{2}$ 塩分付着, 沖縄実橋にお ける 2001 年 5 月の実測值)

塩分付着量が少ない場合の除湿剤による防食効果を 図一16により説明できる. 同図には自然桁と除湿桁内部 の相対湿度および表面に $1 \mathrm{mg} / \mathrm{m}^{2}$ の塩分を付着させた ACMセンサの出力の経時変化を示している. 自然桁内 部では, 湿度が85\%ないし100\%に達することがしばし ば発生し，その時, 有意なACMセンサの出力が認めら れることから, 腐食は発生したと考えられる.これに対 して, 除湿桁内部では, 湿度がほぼ85\%以下に制御され ているため, 有意なACMセンサ出力がほとんど認めら れなく，鋼板の腐食は抑えられたと考えられる。

塩分付着量が多い場合（例えば, $10 \mathrm{mg} / \mathrm{m}^{2}$ 以上の場 合）では，図ー14から分かるように，除湿剤を箱析内 部に設置することにより，鋼板の腐食速度が抑制され たが，腐食発生は防止できなかった. 塩分付着量が多 い場合での鋼板発錆を完全に防止するためには, 相対 湿度をさらに低く制御しなければならないことが分か った.

以上の結果より，除湿剤を用いて箱桁内面の鋼板発 錆を防ぐには, 箱桁内面の不純物付着量を $1 \mathrm{mg} / \mathrm{m}^{2}$ 以 下にコントロールすることが必要であることが分かっ た.

\section{5. 箱桁内部無塗装防錆システムの提案}

実橋箱桁内部の大気腐食性評価結果から分かるよう に, 北海道と沖縄の実橋箱桁内面の一般部の不純物付 着量は少なく，鋼板腐食速度は非常に小さかった．ま た，除湿剂を箱桁内部に設置することにより，箱桁内 部の湿度を長期間 $85 \%$ 以下に制御することができ，結 露水の発生を防.止できた. 箱桁内部の発錆を防ぐには, 除湿剂を箱桁内部に設置すると共に, 箱析内面の不純 物付着量を $1 \mathrm{mg} / \mathrm{m}^{2}$ 以下に抑えることが必要である.

これらの知見に基づいて, 箱桁内部無塗装防錆システ ムを以下のように提案する.

まず, 外部からの水浸入を防止しなければならない. 外部からの水浸入ルートは, 排水管が箱析内部を通過 する構造でなければ, 現場継手ボルト連結部, ハンド ホール部およびドア部等の開口部と考えられる.この ため, 現場継手ボルト連結部, ハンドホール部および ドア部にシーリングを施す等の構造上の改良をすれば, 箱桁内部への水の浸入を防ぐことができる. 特に, 現 場全断面溶接を行う場合, 現場継手部に特別な措置を 施さなくても, 外部からの水の浸入を防止できる.

次に, 結露水の生成を防ぐことが必要である. 箱桁 内部の結露防止には, 図一12 から明らかなように, “自 己呼吸”機能を持つ除湿剂は有効である. 前述のように, 本除湿剂は, 毛細管構造が破壊されない限り，その除 湿効果が半永久的に継続する.この種の除湿剤を箱枌 内部に設置すれば, 結露水の生成が防止でき, ミニマ ムメンテナンスが達成できる.

さらに, 箱桁内面への不純物付着量を $1 \mathrm{mg} / \mathrm{m}^{2}$ 以下 に抑えることが必要である. 結露水がないことを前提 として, 箱桁内部の不純物付着量を低レベルにコント ロールすることにより，鋼材の発錆が防止できる．表 -1 に示す部位ごとの不純物付着量をみると, 飛来塩 分量が非常に多い沖縄の実橋箱析構造では, 人の出入 りによる床部の污染および，スカラップ部，ドア部な どの開口部からの不純物侵入が問題となっている.こ れらの開口部に対して, 密閉性向上などの構造改良を 施し，また，人の出入りによる床部の污染に対して対 策を講じれば, 箱析内部への不純物付着量を低レベル に制御することが可能である.

一方, 箱析内面を無塗装とした場合, 架設後のみな らず，箱析の製作，輸送および架設中においても，一 時的な防錆対策を講じる必要がある. このことを考え ると，箱析に使用する鋼板は，一時的防錆機能を有す る原板プライマー鋼板が最適であると考えられる.

以上をまとめると, 箱桁内面無塗装システムは以下 
のようになる.

(1) 箱桁構造密閉性を向上する等の構造上の改良に より, 外部からの水の浸入を防ぐこと. (万が一, 外部から少量の水が浸入した場合, 原板プライ マー鋼板を使用することにより, プライマー層 の一時的な防錆効果を期待する. 設計上で外部 からの水浸入の可能性がある場合, 箱析内部に 温湿度センサおよび ACM センサを設置し，モ ニタリングを行うことが一つの対策と考えられ る. ACM センサにより漏水が検知された場合, 迅速な対応を行う.)

(2) 除湿剤（または除湿機）の設置により, 結露を 防止すること.

(3) 構造密閉性の向上で不純物付着量を最小限にコ ントロールし，鋼板の腐食を極低レベルに制御 すること.

（4) 製作，輸送および架設過程中の腐食を防止する ため，一時的な防錆機能を有する原板プライマ 一鋼板を使用すること.

また, 現場全断面溶接構造では, 特別な措置を取 らなくても箱析の密閉性が確保できるため, 箱桁内 部無塗装防錆システムをより効果的に適用できるこ とを付記しておく.

本文で提案する箱析内部無塗装防錆システムは, 初 期コストのみならず, ライフサイクルコスト(以下 LCC と略記）の大幅な低減を可能とするシステムである. ここで, $\mathrm{JH}$ 鋼橋標準設計における 3 径間連続箱桁に本 システムを適用した場合の LCC を概算し, 従来の内面 塗装仕様を適用した場合の LCC と比較することで, 本 システムの経済的見地からの有用性を説明する. なお, LCC の算出には以下の条件, 仮定等を用いた.

・本来, ライフサイクルコストを算定する場合, 部材 だけを対象とするのではなく, 発注者（機関），工 一ザー, 第 3 者に関わる総コストを計上すべきであ るが,ここでは, 発注者の立場から, 本システムを 適用した場合の，防食に関わる「初期コスト十維持 管理コスト」におけるコストメリットを示すもので ある.

・割引率および経済成長率は考慮しない.

- 内面塗装の塗替えインターバルは 25 年とする.

- LCC 比較期間は 100 年とする.

・橋梁全体を対象とした場合, 撤去コスト・更新コス 卜を勘案すべきであるが, 防食という観点のみに着 目することから, 撤去・更新コストは比較対象とし ない.

・ LCC 算出のための適用式
表-4 LCC 算出対象塗装系

\begin{tabular}{|c|c|c|}
\hline \multirow{2}{*}{ CASE } & \multicolumn{2}{|c|}{ 塗装系 } \\
\hline & 新設塗装 & 塗替え塗装 \\
\hline CASE 1 & $\mathrm{D}-3$ & $\mathrm{~d}-1$ (3 種ヶレン) \\
\hline CASE 2 & $\mathrm{D}-4$ & $\mathrm{~d}-2$ (3 種ヶレ) \\
\hline CASE 3 & 無塗装 & -二- \\
\hline \multirow{2}{*}{ CASE 4} & 一般部:無機ジ 劢(原板) & \multirow{2}{*}{$\begin{array}{c}\text { 変性工⿺。丶 } 1 \text { 層 } \\
\text { (3 種ケレン) }\end{array}$} \\
\hline & 添接部:変性工术 1 層 & \\
\hline \multirow{7}{*}{ 備 考 } & 形式 & 3 径間連続箱桁 \\
\hline & 橋長 * 幅員 & $\begin{array}{c}211.3 \mathrm{~m} * 10.690 \mathrm{~m} \\
(9.000 \mathrm{~m})\end{array}$ \\
\hline & 支間割 & $3 @ 70 \mathrm{~m}$ \\
\hline & 箱桁幅*高さ & $1.950 \mathrm{~m} * 2.800 \mathrm{~m}$ \\
\hline & 工場塗装面積 & $6528 \mathrm{~m}^{2}$ \\
\hline & 現場塗装面積 & $288 \mathrm{~m}^{2}$ \\
\hline & 鋼重 & 713ton \\
\hline
\end{tabular}

表 -5 LCC 算出結果

\begin{tabular}{|c|c|}
\hline CASE & LCC の相対比 \\
\hline CASE 1 & 0.90 \\
\hline CASE 2 & 1.00 \\
\hline CASE 3 & 0.15 \\
\hline CASE 4 & 0.33 \\
\hline
\end{tabular}

$$
\mathrm{LCC}=\mathrm{I}+\Sigma \mathrm{Mt}
$$

ここに, I は初期コストで, $\mathrm{Mt}$ は $\mathrm{t}$ 年目の維持補修費 用である.

LCC 算出対象とする塗装系を表 -4 に，LCC 算出結 果を表-5 に示す.CASE 1 と 2 は従来の塗装の場合で, CASE 3 と 4 は，本システムを用いた場合である. 表一 5 から分かるように, 本システムを用いた場合は, 塗 装の場合に比べて 6 割以上のコスト低減が期待できる.

\section{6. おわりに}

本研究では，除湿剤を用いた鋼製箱析内部防錆シス テムの開発を目的として，実橋箱桁内部の環境腐食性 および除湿剂による箱析内部の湿度制御と防食効果を 調査した. その結果, 箱枌内面の一般部では不純物付 着量が少なく，鋼板の腐食速度は極めて小さいこと， 除湿剤を箱析内部に設置することにより，結露水の発 生が防止できることが分かった．また，箱析構造の密 閉性の向上, 箱桁内面への不純物付着の防止策, 除湿 剂による箱桁内部の湿度制御などを通して，箱桁内面 の鋼板発錆を防ぐことが可能であることが分かった.

しかしながら, ACM センサおよび暴露試験片による 箱桁内面鋼板腐食状況の計測は, ACM センサと暴露試 
験片が構造（あるいは構造の一部）そのものではない ために, その結果が実構造の腐食状況を完全に反映し ているとは言い切れない面がある. 今後, 内面を無塗 装とした実物大の鋼製箱析を用いての暴露試験を通し て, 箱桁内面鋼板腐食状況を検証していくことが必要 である.

謝辞 : 鋼橋大気腐食の研究に関して, ご指導を頂いた 过川東大名誉教授に感謝の意を表します．また，実橋 試験場を提供して下さった北海道十勝支庁の関係方々 および沖縄総合事務局那覇港湾空港工事事務所の関係 方々にお礼を申し上げます.

\section{参考文献}

1) 村越潤, 名取暢 : 鋼橋の腐食とその原因, 橋梁と基礎, Vol. 27, No. 6, pp.39-44, 1993.

2）藤野陽三: 橋梁の防錆 一ボックス構造内部の腐食環境亡 湿度コントロールによる防錆一, 防食技術, Vol. 38, No. 10, pp.546-552, 1989.

3）藤野陽三, 上田雅俊, 延藤遵 : 鋼ボックス内部の腐食環 境と防錆について, 構造工学論文集, Vol. 36A, pp. 1021-1033, 1990.
4) 上田雅俊 : 東京大学修士論文, 1990.

5) Vassie, P. R.: Corrosion of Structural Steelwork in Bridge Enclosures, Box Section and Anchorage, British Corrosion Journal, Vol. 22, No. 1, pp.37-44, 1987.

6) 松井繁憲, 寺西功, 三田哲也, 藤野陽三 : 鋼箱析内部防 錆実験の報告，鋼構造論文集，Vol. 2, No. 7, pp. 63-71， 1995.

7) 金子正猪, 溝上嘉昭, 内藤真 : 乾燥空気による箱析内部 防食一新尾道大橋一, 橋梁と基礎, Vol. 33, No. 5, pp.31-34, 1999.

8）森 幸夫: 大島大橋箱桁内腐食環境調査, 第 121 回腐食防 食シンポジウム資料, pp.38-45，2001.

9) 内海 靖: 箱析内は良環境一荻安賀高架橋桁内環境調査一, 川田技報, Vol. 21, pp.92-93, 2002.

10) 篠原正, 藤野陽三, 辻川茂男 : ACM 型腐食センサによる 鋼橋のボックス構造内の腐食環境の検討, 第 37 回腐食防 食討論会講演集, C-204, 1990.

11) 斎藤平蔵: 建築気候 (初版 17 刷発行), 共立出版 (株), pp.101-105, 1991.

12）（社）日本規格協会：JS Z 0301 (1989)「防湿包装方法」.

\title{
PREVENTION OF CORROSION INSIDE STEEL BOX GIRDER OF BRIDGE
}

\author{
Jinsun LIAO, Shigenori MATSUI, Moriyoshi KUSHIDA, Tadashi SHINOHARA \\ and Yozo FUJINO
}

The corrosivity inside box girders of steel bridges was investigated. The humidity controlling and rust prevention using a special desiccant were studied. The desiccant used in this study is capable of absorbing and releasing the moisture at high and low humidity respectively. The effects of humidity controlling and rust prevention of the desiccant were confirmed by the field test inside the box girders. On the basis of above investigations, a rust preventing system was proposed, in which the desiccant was used instead of painting inside the box girders. The life-cycle cost for the rust prevention of steel box girders can be remarkably reduced by this rust preventing system. 